\title{
Diffusion of News through Social Media with Reference to the Kiss of Love Movement on Facebook
}

Rupa $\mathrm{P}^{\text {* }}$

\section{Abstract}

Web 2.0 is an interactive medium that has paved the way for the democratization of news. News is no longer the domain of the elite who disseminate it to the masses via mass media. In the age of Web 2.0, where social media rules the roost, every individual is a content generator and a purveyor of information. News is now more viral than ever. Facebook with over a hundred million users in India is the most popular social networking site in India. People use Facebook to connect, like, share and comment on everything from politics to culture to religion and so on. They also use it to disseminate news that they connect with on a personal level; along with their opinions on the same. This way, they become creators and transmitters of information.

The Kiss of Love movement is a non-violent protest against moral policing which began when a Facebook page called 'Kiss of love' asked the youth across Kerala to participate in a protest against moral policing on $2^{\text {nd }}$ November, 2014, at Marine Drive, Cochin. The controversial movement has snowballed into a mass movement which has spread into other states. A campaign of this magnitude has been made possible due to viral diffusion of news, information and comments on Facebook. This study uses quantitative and qualitative

* Assistant Professor, Department of Media Studies, The Oxford College of Arts, Bengaluru, India ; rupapeter@gmail.com 
tools to study the diffusion of news with regard to the Kiss of Love movement through Facebook in an attempt to shed more light on the diffusion process of information through social media.

Keywords: News Diffusion, Social Media, Facebook, Kiss of Love, Viral News

\section{Introduction}

Diffusion, according to the Merriam Webster dictionary is the spread of cultural elements from one area or group of people to others by contact. Diffusion of news is the process in which, news is disseminated to a large audience both through mass media channels and through interpersonal social networks.

\section{a) Traditional News Diffusion: From Mass Media to the Masses}

Traditionally, news diffusion takes place when elites who have access to production and dissemination channels of mass media use it to spread information, education and entertainment to the masses. The audiences in this form of communication are by and large, passive recipients of information. Newspapers, television and radio provide news and infotainment and the audience dutifully receive this information. Options to give feedback are limited and the voice of the audience is very rarely heard.

\section{b) Social Media and the New Process of News Diffusion}

With the arrival of the internet, things have changed. And whenWeb 2.0, powered by social mediaarrived, there was a definite change in the status quo. Web 2.0 with its legion of blogs, social networking sites like Facebook, microblogging sites like Twitter, multimedia sites like YouTube, social bookmarking sites like Reddit and mobile networking applications like Whatsapp is a highly interactive medium that has paved the way for the democratization of news. In the age of Web 2.0, where social media rule the roost, every individual is a content generator and a purveyor of information. News is now more viral than ever. Every user is a part of the news diffusion process. And individuals themselves set the agenda on what their peers need to think and talk about through their social media messages and uploads. 
Social media, which has ensured that the power rests in the hand of the individual, has slowly emerged as an effective catalyst for social change. From the Arab Spring to the Anna Hazare Anti-corruption movement closer home, social media has been successfully used by social change agents to create and diffuse new waves of thought that have surely altered the social fabric of countries.

Facebook with hundred million users in India is the most popular social networking site in India. People use Facebook to connect, like, share and comment on everything from politics to culture to religion and so on. They also use it to disseminate news that they connect with on a personal level, along with their opinions on the same. This way, they become creators and transmitters of information.

\section{c) Kiss of Love Movement}

The Kiss of Love movement is a non-violent protest against moral policing which started in Kerala and later spread to other parts of India. The movement began when a Facebook page called 'Kiss of love' asked the youth across Kerala to participate in a protest against moral policing on November 2nd, 2014, at Marine Drive, Cochin. The movement had 145,205 likes in Facebook as on December $5^{\text {th }}, 2014$.

The controversial protest has snowballed into a mass movement which has spread into other states. A movement of this magnitude has been made possible due to viral diffusion of news, information and comments on Facebook.

\section{Theoretical Framework}

According to the diffusion of innovation theory by Everett Rogers, the diffusion process takes place when an innovation is communicated through channels over a period of time to the participants in a society. The theory states that the spread of a new idea is influenced by four elements: the innovation, communication channels, time, and the social setup. Also, the entire diffusion process depends heavily on human resources. Diffusion of news via social media networks also follows the same pattern. When an idea or a news story captures the imagination of social media users, 
the communication channel which is democratic in itself becomes active and the information is transmitted virally and slowly percolates the social system over a period of time. The Kiss of Love movement, which owes its origins to social media, uses the interactivity, virality and instantaneous nature of the medium and the active participation of its users to diffuse news about the movement to a number of people.

\section{Review of Literature}

According to Kim et al., (2014) when it comes to crowd phenomena in the diffusion of news through social media, news is the most actively diffused, Social Networking Sites (SNS) is the most reactive and blog is the most persistent. It was identified that SNS is a lazy creator but a diligent adopter of information.

King et al. (2014)while studying the diffusion of news regarding the death of Osama bin Laden among college students found that the majority had firstheard of Bin Laden's death through a new media source like text message, internet news site, or social networking site and a significant number had first heard the news through a social networking site.

According to DivyaKumari and Chandunavar (2013) social media is a cultural melting point and people exchange culture-related information such as festivals, food, languages, clothes and so on through social media. Information diffusion related to culture happens actively in social media.

Bertsche (2010) explains that new social media means that everyone is a publisher and everyone is a critic. In social media, everyone has the opportunity to express their opinions and participate in dialogue through a common virtual medium.

Wohn et al. (2011) identified that users employed Facebook for social information uses like information-seeking, organizing events and establishing common ground. Users were organizing events through Facebook by creating groups and posting status updates to their networks. This way, they actively participated in communityfocused activities. 
According to Veltri N.F. and Elgarah (2009), social networking depends on continuous user participation. Though the diffusion of social media across the globe has different effects on individual cultures, it nevertheless promotes interconnectedness and understanding among global societies.

According to Barua (2013), the spread of information or opinion on social media is very rapid, stronger than any media because likeminded people are connected and also because social media renders a personal touch to information diffusion.

Lopez A.R. (2014) found that social media is a predictor of protest activity because of its ability to mass organize people to voice out their concerns related to social issues.

Harlow S. (2011) while studying the social media campaign that called for the resignation of the Guatemalan President Alvaro Colom in relation to a posthumous video by prominent lawyer Rodrigo where he blamed the President for his murder, found that Facebook was used to mobilize an online movement that moved offline.The comments of the users which were related to the protests and also motivational comments, in addition to the use of interactive elements of Facebook, helped organize massive protests demanding justice and an end to violence.Facebook provided the means to bypass traditional news gatekeepers, allowing movement participants to publish their own opinions and publicize activities. This contributed to the transition of the online movement to offline action.

Moghanizadeh (2013) while studying the role of social media in Iran's Green Movement found that social media was a highly effective tool which helped in the mobilization of the masses for the Green Movement. The study concluded that social media tools like Facebook, YouTube, Twitter, text messaging, and photo sharing could play a consequential function in facilitating participation in social movements. From the organizer's side, these tools are effective in creation of mobilization potentials, formation and activation of recruitment networks, inducing motivations for participation and removing barriers to participation. From the perspective of the general public, social media provides the motivation and the stimulus to participate. Social media sites also 
inform people about the location, date and time of activities related to the movement.

According to Vitak et al. (2010) young Facebook user's political participation in the 2008 U.S. Presidential Election was high on information but was low in the intensity of resources. The study found that youngsters generally felt that Facebook offered appropriate opportunities for political self-expression.

Sauter and Bruns (2013), while studying social media coverage in Australian media report that the general publics are predominantly portrayed as using social media to campaign, stand up for their rights, and support particular causes.

Eltantawy and Wiest (2011) while studying the use of social media in the 2011 Egyptian revolution identified that social media played a significant role in the revolutions in the Arab world. In Egypt, activists used social media since 2009 to engage in online discussions and debates on socio-political conditions. This sowed the seed for a full-forcerevolution. Social media thus emerged as a resource for collective action. Social media helped add swiftness to the process of information dissemination, helped strengthen ties among activists, and increased interaction. The revolution demonstrates the opportunities inherent in social media for largescale mobilization and implementation of social movements.

Vivian and Elizabeth (2015) while studying social media mobilization in Nigeria identified that social media can become an effective, alternative tool for social mobilization, as this medium has the ability to engage the audience. It has the ability to inspire active action and can be used to engage public for social development.In a developing country such as Nigeria, social media is effective for mobilization as it lowers the costs of sensitization, participation, organization, recruitment and training of different groups. However, its effectiveness depends on how effectively civil society, government and the public use them and how accessible they are to people. In Nigeria, social media access is by and large restricted to urban areas and to young adult males. Social media tools can be used for building civic engagement and sensitization of the public as it helps debate on local issues transparently and encourages people to involve in developmental issues. 


\section{Research Methodology}

\section{a) Statement of the Problem}

The wide visibility and reach of the Kiss of Love movement owes itself to the medium of news diffusion - social media. Facebook played a very major role in the diffusion of news regarding this movement. This study uses quantitative and qualitative tools to study the diffusion of news with regard to the Kiss of Love movement through Facebook in an attempt to shed more light on the information diffusion process of information through social media.

\section{b) Research Design}

The study uses qualitative and quantitative elements to identify the news diffusion process of the Kiss of Love movement through Facebook.

- A qualitative study was undertaken to understand the trends in news diffusion through social media by analyzing the Kiss of Love movement on Facebook. The original Kiss of Love page (https://www.facebook.com/ kissoflovekochi?fref $=$ ts) was studied to analyze the news diffusion process.

For the purpose of this study, the posts/status updates of two days per week starting from the Facebook page launch date (24th October 2014) were selected and analyzed for news diffusion. The selection of the two days that were studied, was based on the popularity of the content (measured in terms of the number of likes) posted on those days. The news diffusion process was analyzed in terms of the likes, shares and comments on the page. A content analysis of the status updates and the comments section was done to identify the trends in opinion as news was diffused to a wider audience and the movement gained greater visibility on Facebook.

- A small quantitative study was also conducted among 100 respondents based in Bangalore to understand how they acquired information about the Kiss of Love campaign and their opinions on the same. This would shed light on social 
media's role in the news diffusion process in a real-time setting against various other media.

\section{Data Analysis and Interpretation:}

\section{a) Analysis of the Data Collected Through the Kiss of Love Facebook Page:}

Data regarding the number of likes, shares and comments from the selected posts were collected and analyzed from The Kiss of Love Facebook page to study the news diffusion trends.

Number of Posts on the Kiss of Love Facebook Page

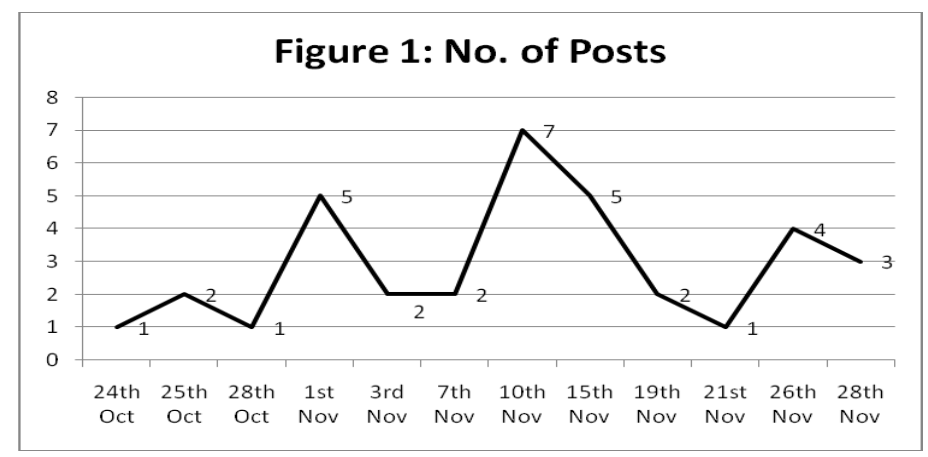

The Kiss of Love campaign was launched on $24^{\text {th }}$ October,2014 with a poster announcement. The number of posts or status updates increases around 1st November, 2014 with 5 posts and then goes on to peak on $10^{\text {th }}$ of November with 7 posts. There is intense activity on the Facebook page on $10^{\text {th }}$ of November with posts on Kamal Hassan's support to the movement, an interview with the founder of the movement and updates on Kiss of Love in Kozhikode. It should be noted that the number of likes, shares and comments are highest on the $10^{\text {th }}$ of November which has the maximum number of posts. 
Number of Likes on the Kiss of Love Facebook Page

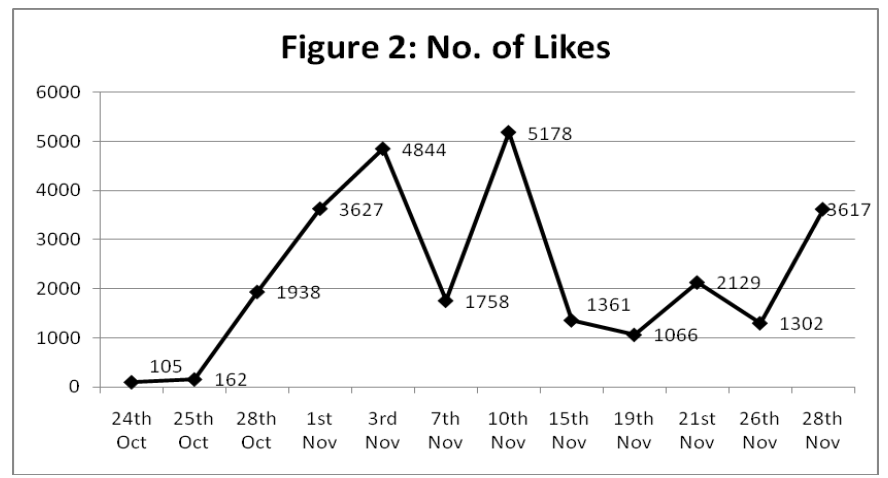

Likes) on the $10^{\text {th }}$ of November, 2014which has the highest number of posts in a day. This is followed by the $3^{\text {rd }}$ of November which has 4844 Likes and the $1^{\text {st }}$ of November with 3627 Likes. It cannot be assumed that an increase in the number of Likes corresponds to an increase in the number of posts. Content of the posts are also a major factor for the increase in the number of Likes.

Celebrity posts are most Liked by respondents as posts on Kamal Hassan's support (10 th $N o v e m b e r)$, TaslimaNasreen's support (3 $3^{\text {rd }}$ November) and Mohan Lal's support (21 st November with 2129 Likes) receive the maximum number of Likes. In fact, the most Liked post is Mohan Lal's support for the movement which has garnered 2129 Likes on $21^{\text {st }}$ November.

Number of Shares on the Kiss of Love Facebook Page

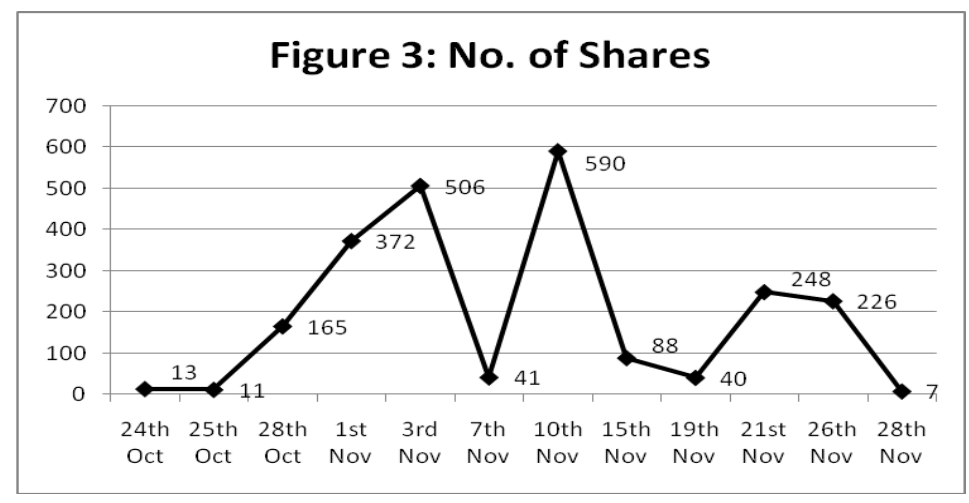


The number of shares of Facebook posts from the Kiss of Love Facebook page peaked on the $10^{\text {th }}$ of November with 590 shares, this is followed by the $3^{\text {rd }}$ of November with 506 shares and the $1^{\text {st }}$ of November with 372 shares.

Shares are a means of spreading or diffusing information pertaining to the Kiss of Love movement. The number of shares jumped from just 13 on the launch date which was $24^{\text {th }}$ October and went up to 165 on the $28^{\text {th }}$ of October. The highest number of shares were on the $10^{\text {th }}$ of November when the number of posts were also highest at 7 . Content mattered when it came to sharing information about the Kiss of Love movement. Mohan Lal's support of the event which was posted on $21^{\text {st }}$ November received the highest number of shares of a single post with 248 shares. This was followed by Kamal Hassan's post supporting Kiss of Love which was shared 141 people. Celebrity support led to a greater diffusion of news.

Number of Comments

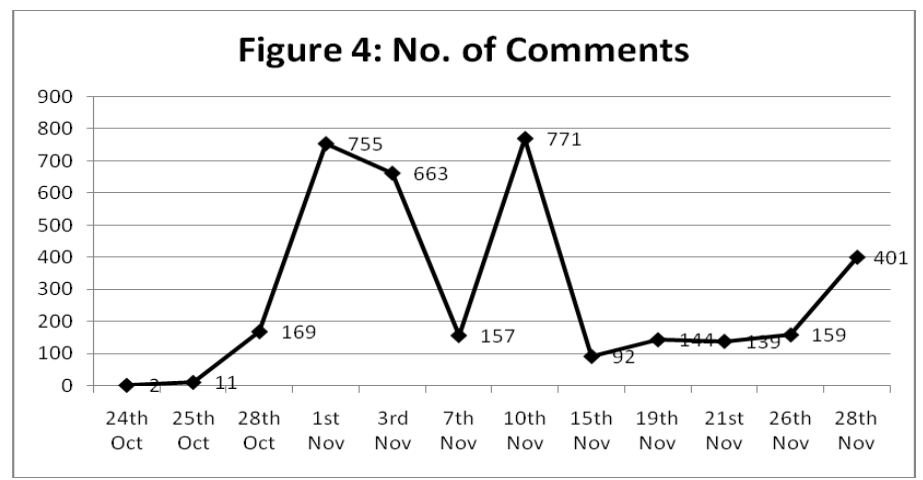

The highest number of comments on the Kiss of Love Facebook page was on the 10 th of November, 2014 with 771 comments which also corresponds to the highest number of posts in a day. This is followed by $1^{\text {st }}$ of November with 755 comments and $3^{\text {rd }}$ of November with 663 comments. Comments were both positive and negative. Posts related to celebrities received were heavily commented upon. 


\section{b) Content Analysis of Kiss of Love Facebook Page}

A content analysis of the selected posts and their corresponding comments was also carried out. The analysis and interpretations are presented below:

Content Analysis of Posts/Status Updates:

- Posts/ Status Updates on Kiss of Love Facebook page included posters announcing the different events, photographs, videos, interviews and articles supporting the event.

- On the launch date, 24th October, 2014, the Kiss of Love started with a simple poster urging people to express their love with a Kiss. Majority of the posts till the first of November were posters announcing the date the event would be held.

- On 1 1'November, 2014, photographs were posted which showed real people (supporters of the movement) kissing in public. These would be the innovators, who readily accepted this diffusion of news and decided to act on it.

- Photographs of Kiss of Love protests happening around the country received a large number of likes and shares and led to a greater diffusion of news.

- On 3rd November, 2014, there was a post of noted Bangladeshi author, Taslima Nasreen's statement supporting the event through her Twitter handle. This post received a large number of likes (1350) and shares (119), which led to a greater diffusion of news regarding the movement. There was also a post criticizing the opponents of the movement which garnered 3494 likes, 599 comments and 388 shares.

- There was some heavy activity on the Kiss of Love Facebook page on 10th November, 2014 with posts on Actor Kamal Hassan's support for the event, a link to an interview with Rahul Pasupalan, the core organizer of the event and information on the Delhi Kiss of Love protest. This day garnered the maximum number of likes, shares and 
comments. The diffusion of news was highest on this day within the purview of this study.

- On $21^{\text {st }}$ November, there was a single post that quoted actor Mohan Lal's bite from ManoramaNews TV in which he extended his support to the Kiss of Love movement. This single post garnered 2129 likes, 248 shares and 139 comments, the majority of which were positive.

- Posts that had celebrities like actors Kamal Hassan, Mohan Lal and TV personality Arundhati voicing their support for the event received a large number of likes and shares.

Content Analysis of Kiss of Love Comments:

- The Comments section of the Kiss of Love Facebook page was very active and saw great participation from day one. Discussion, debates and arguments both for and against the event were carried out back and forth for every post and status update.

- The comments peaked on $10^{\text {th }}$ of November which received 771 comments.

- Comments on the Kiss of Love Facebook page were in the form of text, videos, posters, emoticons and memes.

- Positive comments expressed support towards the movement. Supporters of the movement commented that it is right to express feelings in public and moral policing should be stopped.

- Negative comments were equally forceful and sometimes used a lot of foul language, personal attacks and threats to the Kiss of Love protestors. Negative comments spoke about the movement being against Indian culture and against any sense of decency.

- The highest number of positive comments were received when celebrities posted their solidarity towards the event. Posts on Kamal Hassan, Mohan Lal and TV anchor Arundhati's expression of support for Kiss of Love received mostly positive comments. Post on Taslima Nasreen's support received the most negative comments 


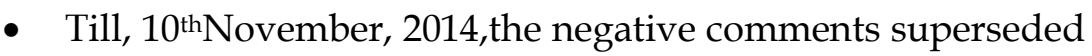
positive comments. Post $10^{\text {th }}$ November, the movement became a national one with posts from Delhi, Chennai and Hyderabad and celebrities came forward to support the event. From there on, the number of positive comments increased in relation to the negative ones. By $28^{\text {th }}$ November, the number of positive comments was greater than the negative comments.

\section{c) Analysis of the Data Collected Through a Questionnaire among General Public in Bangalore:}

A quantitative study was conducted among the general public in Bangalore using the questionnaire as a tool to gauge the news diffusion levels about Kiss of Love campaign. 100 respondents answered the questionnaire and the data was interpreted using percentiles.

Table 1: Heard about the Kiss of Love campaign

\begin{tabular}{|l|c|}
\hline \multicolumn{1}{|c|}{ Heard of Kiss of Love } & Percentage \\
\hline Yes & $75 \%$ \\
\hline No & $22 \%$ \\
\hline Don't remember & $3 \%$ \\
\hline
\end{tabular}

$75 \%$ of the respondents had heard about the Kiss of Love campaign. $22 \%$ of the respondents had never heard of Kiss of Love.

Table 2: Source of Information Regarding Kiss of Love

\begin{tabular}{|l|c|}
\hline \multicolumn{1}{|c|}{ Source } & Percentage \\
\hline Newspapers & $58.7 \%$ \\
\hline Television & $45.3 \%$ \\
\hline Radio & $5.3 \%$ \\
\hline Internet news & $26.7 \%$ \\
\hline Social Media Sites & $54.7 \%$ \\
\hline Mobile Apps & $12 \%$ \\
\hline While talking to friends/family & $24 \%$ \\
\hline
\end{tabular}

$58.7 \%$ of the respondents have read about the Kiss of Love from newspapers, while $54.7 \%$ of the respondents heard about it from social media sites and $45.3 \%$ from Television channels. 
Table 3: Diffusion of News through Social Media Site/Mobile Applications

\begin{tabular}{|l|l|}
\hline SMS/Mobile App & Percentage \\
\hline Facebook & $54.6 \%$ \\
\hline Twitter & $20 \%$ \\
\hline Google+ & $5.3 \%$ \\
\hline YouTube & $12 \%$ \\
\hline Whatsapp & $22.7 \%$ \\
\hline Hike & $10.7 \%$ \\
\hline
\end{tabular}

The majority of the respondents $(54.6 \%)$ who received information regarding Kiss of Love through social media/mobile apps received it through Facebook. This was followed by Whatsapp (22.7\%) and Twitter (20\%).

Table 4: Visited/Liked/Shared/ Commented on Kiss of Love

\begin{tabular}{|l|c|c|c|c|}
\hline Response & $\begin{array}{c}\text { Visited } \\
\text { Kiss of Love } \\
\text { FB page }\end{array}$ & $\begin{array}{c}\text { Liked } \\
\text { Kiss of Love } \\
\text { Posts }\end{array}$ & $\begin{array}{c}\text { Shared } \\
\text { Kiss of } \\
\text { Love Posts }\end{array}$ & $\begin{array}{c}\text { Commented } \\
\text { on Kiss of } \\
\text { Love posts }\end{array}$ \\
\hline Yes & $24 \%$ & $16 \%$ & $8 \%$ & $5.3 \%$ \\
\hline No & $76 \%$ & $81.3 \%$ & $90.7 \%$ & $93.3 \%$ \\
\hline $\begin{array}{l}\text { Don't } \\
\text { remember }\end{array}$ & 0 & $2.7 \%$ & $1.3 \%$ & $1.3 \%$ \\
\hline
\end{tabular}

Despite $54.6 \%$ of the respondents receiving information on Kiss of Love through Facebook, only a smaller percentage (24\%) have actually visited the site. The majority of the respondents $(81.3 \%)$ have never given a 'Like' to Kiss of Love posts on Facebook. Diffusion of news through Facebook shares have been minimal with only $8 \%$ of the respondents sharing posts related to Kiss of Love.The majority of respondents $(93.3 \%)$ have not given any comments on Kiss of Love posts on Facebook.

Table 5: Social media has helped popularize the Kiss of Love movement

\begin{tabular}{|l|c|}
\hline SM helped popularize Kiss of Love & Percentage \\
\hline Yes & $65.3 \%$ \\
\hline No & $6.7 \%$ \\
\hline Don't know & $28 \%$ \\
\hline
\end{tabular}


The majority of the respondents $(65.3 \%)$ are of the opinion that social media helped popularize the Kiss of Love movement, while $28 \%$ of the respondents have no opinion regarding the same.

\section{Findings:}

- Newspapers, social media sites and television were the most popular media for diffusion of news regarding the Kiss of Love movement.

- Facebook is the social media site that widely helped in the diffusion of news regarding Kiss of Love. Apart from this, Whatsapp and Twitter have played an important role in the news diffusion process.

- Kiss of Love's Facebook page is very popular with 145, 205 likes as on $5^{\text {th }}$ December 2014.

- The number of likes, shares and comments per day increased with the increase in the number of posts.

- Content of the posts is very important as posts with meaningful and controversial content gained a large number of likes and shares.

- Celebrities have a positive effect in the diffusion of news on Kiss of Love through Facebook.

- As the diffusion of news about this movement spreads across social media and as the movement spread from Kerala to other states and as more celebrities expressed their support to the movement, the opinion wave towards Kiss of Love shifted from a negative one towards a more positive opinion.

- Majority of the respondents in Bangalore have heard of the Kiss of Love movement. However, a majority of them have not visited the Kiss of Love Facebook page.

- Majority of the respondents have not liked, shared or commented on the Kiss of Love Facebook posts.So, diffusion of news doesnot necessarily translate to active participation.

- Majority of the respondents feel that social media has helped popularize the Kiss of Love movement. 


\section{Conclusion:}

Social media plays a very important role in thediffusion of news. Social media sites like Facebook serve as a democratic forum where people actively participate and decide on the type of news they would like to disseminateand the way in which they would like to do so. Celebrities serve as opinion leaders in the social media milieu and help shape public opinion. However, diffusion of news does not always translate to active participation by the general population. Social media has definitely helped enhance the visibility, reach and popularity of news regarding the Kiss of Love movement.

\section{References}

Baran, S. J., \& Davis, D. K. (2008). Mass communication theory: Foundations, ferment, and future (5th ed.). Boston, MA: Wadsworth Cengage Learning.

Barua, S. D. (2013). New Media as Democratic Space in India. Social Media and New Technologies. New Delhi: Kanishka.

Bridging Babel: New Social Media and Interreligious and Intercultural Understanding. (n.d.). Retrieved April 17, 2015, from https://berkleycenter.georgetown.edu/publications/ bridging-babel-new-social-media-and-interreligious-andintercultural-understanding

Dunu, I. V., \& Uzochukwu, C. E. (2015, April). Social Media: An Effective Tool for Social Mobilization in Nigeria IOSR-Journal of Humanities and Social Sciences Retrieved June 03, 2015, from http://iosrjournals.org/iosr-jhss/papers/Vol20issue4/Version-3/C020431021.pdf

Eltawny, N., \& Wiest, J. B. (n.d.). The Arab Spring| Social Media in the Egyptian Revolution: Reconsidering Resource Mobilization Theory. Retrieved December 09, 2014, from http://ijoc.org/ index.php/ijoc/article/view/1242

Harlow, S. (2012, March 19). Social media and social movements: Facebook and an online Guatemalan justice movement that moved offline. Retrieved January 10, 2015, from http://nms.sagepub.com/content/14/2/225.short 
Kim, M., David, N., \& Peter, C. (n.d.). Trends of News Diffusion in Social Media Based on Crowd Phenomena. Retrieved January 11, 2015, from http://wwwconference.org/proceedings/ www2014/companion/p753.pdf

King, L. J., Glascock, J., \& Levitt, L. (n.d.). The Death of Osama Bin Laden: News Diffusion and the Role of New Media. Retrieved January 12, 2015, from http://connection.ebscohost.com/c/ articles/100060530/ death-osama-bin-laden-news-diffusionrole-new-media

Kumari, D. K., \& Chandunavar, K. (2013). Impact of New Media on Indian Cultural Discourse. Social Media and New Technologies. New Delhi: Kanishka.

Lopes, A. R. (2014, April 01). The Impact of Social Media on Social Movements: The New Opportunity and Mobilizing Structure Retrieved January 12, 2015, from https://www.creighton.edu/ fileadmin/user/CCAS/departments/PoliticalScience/Journal_ of_Political_Research_JPR_/2014_JSP_papers/Lopes_JPR.pdf

Moghanizadeh, S. (2013, May). The role of social media in Iran's Green Movement. Retrieved January 16, 2015, from https://gupea.ub.gu.se/bitstream/2077/34206/1/gupea_2077 _34206_1.pdf

Sauter, T., \& Bruns, A. (2013, July 01). Social Media in the Media: How Australian Media Perceive ... Retrieved January 15, 2015, from http://www.cci.edu.au/socialmediainthemedia.pdf

Veltri, N. F., \& Elgarah, W. (2009). AIS Electronic Library (AISeL). Retrieved January 17, 2015, from http://aisel.aisnet.org/ sais2009/.

Vitak, J., Zube, P., Smock, A., Carr, C. T., Ellison, N., \& Lampe, C. (2010, July 22). It's Complicated: Facebook Users' Political Participation In the 2008 Election. Retrieved January 20, 2015, from http://www.academia.edu/ 412946/Its_Complicated_Facebook_Users_Political_Participatio n_In_the_2008_Election

Wahn, D., Lampe, C., Vitak, J., \& Ellison, N. B. (2011, February 11). Coordinating the Ordinary: Social Information Uses of Facebook by Adults. Retrieved January 25, 2015, from https://msu.edu/ nellison/Wohn_et_al2011_iConf.pdf 